\title{
Formula feed preparation: helping reduce the risks; a systematic review
}

\author{
M J Renfrew, P Ansell, K L Macleod
}

Arch Dis Child 2003;88:855-858

See end of article for authors' affiliations

.....................

Correspondence to: Professor M Renfrew, Mother and Infant Research Unit, University of Leeds, 22 Hyde Terrace, Leeds LS2 9LN, UK:

m.j.renfrew@leeds.ac.uk

Accepted

17 December 2002

\begin{abstract}
Aims: To assess what is known about the risks associated with errors in reconstituting the present generation of infant formula feeds, and to examine which methods are likely to be safest.

Methods: Systematic review, and examination of the range of infant formula products currently on sale in the UK. Studies from developed countries conducted after 1977 were included. All studies investigating the reconstitution of formula feeds for full term, healthy babies were eligible. Parameters studied were: measures of accuracy of feed reconstitution including fat, protein, total solids, energy content, and osmolality of feed; weight of powder in scoop; and reported method of preparing feed and measuring powder. Formula products were collected from one large UK supermarket in 2002. Number of different types of infant formula preparations available for sale were determined, together with scoop sizes for powdered preparations.

Results: Only five studies were identified, none of adequate quality or size. All found errors in reconstitution, with a tendency to over-concentrate feeds; under-concentration also occurred. Thirty one different formula preparations were available for sale in one UK supermarket, with a range of scoop sizes. Some preparations had never been tested.

Conclusions: There is a paucity of evidence available to inform the proper use of breast milk substitutes, and a large array of different preparations for sale. Given the impact incorrect reconstitution of formula feeds can have on the health of large numbers of babies, there is an important and urgent need to examine ways of minimising the risks of feed preparation.
\end{abstract}

B reast feeding is the safest way to feed babies. For the majority of babies in all countries it is a perfect source of nutrition ${ }^{1}$ and is available, ready-to-feed, via a clean delivery system. Breast feeding protects against infection, ${ }^{2-4}$ and has benefits for health in childhood and beyond. ${ }^{5-7}$ National and international agencies recognise the superiority of breast feeding and support it unequivocally. ${ }^{18}$ However, many babies in many countries are not breast fed.

In the UK, in spite of initiatives to encourage more women to breast feed their babies, and to do so for longer, ${ }^{9-11}$ over the past 20 years there has been no real change in the proportion of babies who are breast fed at birth. ${ }^{12}$ In 2000 , by $4-10$ weeks of age (the first stage of the most recent national survey), $75 \%$ of babies were either exclusively fed on formula milks, or were receiving a combination of breast and formula feeds. ${ }^{12}$ These figures, which reflect infant feeding patterns in many westernised populations, highlight the fact that most babies in the UK are fed, wholly or in part, on breast milk substitutes. It is, therefore, important that while attempting to increase the prevalence and duration of breast feeding, ${ }^{9}{ }^{13-15}$ attempts should also be made to minimise the risks associated with artificial feeding.

The most common breast milk substitutes are formula feeds manufactured as dried powders, reconstituted by adding water. Wrongly reconstituted feeds may have serious consequences for babies and during the 1970s there was concern about the apparently high incidence of hypernatraemic dehydration complicating acute gastroenteritis. ${ }^{16-19}$ These and other reports $\mathrm{s}^{20-25}$ suggested the problem was due to babies receiving dangerously high solute feeds, in large part a consequence of mothers preparing over-concentrated feeds. Since these studies were carried out, however, there have been changes in the composition of formula milks. National Dried Milk was withdrawn in 1977 and the use of similar formulae based on unmodified dried or evaporated milk is no longer recommended ${ }^{26}$ All infant formulae marketed in the UK now have to comply with compositional guidelines published by the Department of Health, drawn up to ensure artificial feeds are as close in formulation as possible to human milk. ${ }^{27}$ There have also been developments in the ways in which formulae are marketed and sold. For example, parents can now buy formula milk as ready-to-feed preparations and in premeasured sachets.

In contrast to the attention received by hypernatraemic dehydration associated with unsuccessful breast feeding, ${ }^{28} 29$ there appears to have been no further investigation of this issue in developed countries in the past two decades, although the problem continues to receive attention in developing countries. ${ }^{30}$

The aim of this review is to assess and update what is known about the risks associated with errors in reconstituting the present generation of infant formula feeds, and to examine which methods are likely to be safest.

\section{METHODS}

A systematic review was carried out in which relevant studies were identified, analysed, and summarised. To establish the context for the review, we also examined the range of products on sale in one large UK supermarket.

\section{Systematic review}

Inclusion criteria

Studies carried out in developed countries for which data were collected after 1977 were included. All studies investigating the reconstitution of formula feeds for full term, healthy babies were eligible for inclusion, regardless of study design. No quality criteria were introduced as so few studies were identified. Non-English citations were included, but studies carried out in developing countries were excluded, as the issues are different in such dissimilar settings. 
Table 1 Studies fulfilling the criteria* for this review

\begin{tabular}{|c|c|c|c|c|c|}
\hline Study & Design & Setting & Participants & Samples analysed & Outcome measures \\
\hline Jacob, $1985^{31}$ & Interview & UK & $\begin{array}{l}30 \text { mothers living in catchment } \\
\text { area of five } \mathrm{CHCs}\end{array}$ & - & $\begin{array}{l}\text { Reported method of } \\
\text { preparing feed and } \\
\text { measuring powder }\end{array}$ \\
\hline $\begin{array}{l}\text { McJunkin et al, } \\
1987^{32}\end{array}$ & $\begin{array}{l}\text { Interview; reconstituted milk } \\
\text { samples analysed }\end{array}$ & USA & $\begin{array}{l}175 \text { mothers attending one urban } \\
\mathrm{CHC}\end{array}$ & $\begin{array}{l}133 \text { reconstituted feeds } \\
\text { provided by mothers }\end{array}$ & $\begin{array}{l}\text { Fat, protein, and total } \\
\text { solids content of feed }\end{array}$ \\
\hline $\begin{array}{l}\text { Lilburne et al, } \\
1988^{33}\end{array}$ & $\begin{array}{l}\text { Interview; reconstituted milk } \\
\text { samples analysed }\end{array}$ & Australia & 272 mothers attending $19 \mathrm{CHCs}$ & $\begin{array}{l}34 \text { reconstituted feeds provided } \\
\text { by mothers and unknown } \\
\text { number of reconstituted feeds } \\
\text { prepared in hospital kitchen }\end{array}$ & $\begin{array}{l}\text { Reported method of } \\
\text { preparing feed and } \\
\text { measuring powder; } \\
\text { osmolality of feeds }\end{array}$ \\
\hline Jeffs, $1989^{34}$ & $\begin{array}{l}\text { Dry milk powder measured } \\
\text { from an open packet with } \\
\text { product's own scoop }\end{array}$ & UK & 28 mothers attending two $\mathrm{CHCs}$ & $\begin{array}{l}84 \text { scoops of dry powder } \\
\text { measured by mothers }\end{array}$ & Weight of powder \\
\hline $\begin{array}{l}\text { Lucas et al, } \\
1991^{35}\end{array}$ & $\begin{array}{l}\text { Reconstituted milk samples } \\
\text { analysed }\end{array}$ & UK & $\begin{array}{l}19 \text { mothers included in a } \\
\text { randomised trial of ready-to-feed } \\
\text { and powdered formula }\end{array}$ & $\begin{array}{l}\text { Median of } 5 \text { (range } 3-6 \text { ) } \\
\text { reconstituted feeds provided by } \\
\text { each mother }\end{array}$ & Energy content of feed \\
\hline
\end{tabular}

\section{Literature search}

Two authors (KLM and PA) independently searched for articles from Medline (1966 to April 2002), Cinhal (1966 to April 2002), Web of Science, and the Cochrane Database of Systematic Reviews, with identical results. A broad search strategy was used, initially for the mesh word "bottle feeding" and its variants, which identified 2268 references; 150 of these were broadly related to bottle feeding and formula preparation, and a further 83 were subsequently identified from the reference lists of relevant studies. It was possible to exclude a number of papers by reviewing the abstracts; all those that could not be clearly excluded were retrieved and reviewed, together with all studies that appeared eligible.

As this strategy produced only three eligible studies, further searches were carried out in Medline using the key words "feed*", "fed", "artificial" "formula*", "milk*", "infant", "baby", "reconstitut*", "scoop*", "dehydration", "hypernatraemia", and "gastroenteritis". This yielded one additional paper, plus a letter reporting findings on the reconstitution of powdered formula from the pilot phase of an investigation of formula feeding and infant growth. Table l summarises key attributes of the papers.

\section{RESULTS}

The five studies fulfilling our review criteria were published between 1985 and 1991. ${ }^{31-35}$ No eligible studies published later than 1991 were found. An additional nine investigations published between 1972 and $1979^{17-25}$ were identified, plus 138 articles that were either commentaries on the subject or were studies of related topics.

\section{Quality of the included studies}

Participants in four of the eligible studies were mothers of artificially fed babies who had been selected or identified through routine child health or welfare clinics ${ }^{31-34}$; those in the fifth ${ }^{35}$ were bottle feeding mothers recruited from a postnatal ward for a randomised trial of ready-to-feed and powdered formula. ${ }^{36}$ The numbers of participants in each study varied considerably (table 1). The three smallest studies were from the UK and had only 30, 28, and 19 participants respectively. ${ }^{31}{ }^{34} 35$ Of the two larger studies, that by Lilburne and colleagues ${ }^{33}$ was most representative of the wider population of mothers with young babies. It recruited and interviewed 272 mothers from 19 clinics in two areas of Australia, selected because of their different characteristics (one area described as predominantly working class, the other as middle class), although unfortunately only 34 samples of reconstituted feed were obtained for analysis. ${ }^{33}$ The remaining study, by McJunkin et al in the USA, ${ }^{32}$ enrolled 175 urban mothers and obtained 133 feed samples: $95 \%$ of the mothers included were black and on low incomes, with more than half entitled to free infant formula or receiving food stamps.

All five were descriptive studies but they varied in many other respects, with different designs and different outcome measures (table 1). Of the four main studies, one interviewed mothers about their feeding practices ${ }^{31}$; one interviewed mothers and analysed samples of reconstituted feed provided by the mothers ${ }^{32}$; one interviewed mothers and analysed and compared samples of feed provided by mothers and prepared in a hospital kitchen ${ }^{33}$; and one weighed dried milk powder measured by mothers with a scoop supplied with the product. ${ }^{34}$ All these studies were concerned with the reconstitution of dried milk powder, measured with the product's own scoop; only the study by McJunkin and colleagues ${ }^{32}$ included ready-to-feed and concentrated liquid preparations. The fifth study ${ }^{35}$ was part of the pilot phase of a small, randomised trial comparing ready-to-feed and powdered formula, the outcomes of the main study being measures of infant growth such as body weight and head circumference. ${ }^{36}$ Only mothers of babies given powdered formula were included in the investigation of formula preparation: it measured the energy content of reconstituted milk samples using potassium content as a marker of feed strength. ${ }^{35} 36$

\section{Findings of the review}

It is difficult to interpret the results of any of these studies with confidence as a result of their methodological problems and small size. However, they all found errors in reconstitution with a tendency to over-concentrate feeds, although underconcentration also occurred.

\section{Products available to parents}

An extensive array of infant formula feeds is available in the UK. Table 2 lists those currently sold (April 2002) in one major supermarket as suitable for normal newborns. Of the 14 products, 11 were cows' milk formulae (five whey dominant, five casein dominant, one $100 \%$ whey protein) and three were soya based products. Many of these formulae come as ready-tofeed preparations and/or in premeasured sachets, as well as in traditional powder and scoop formulations, leaving parents, and their advisers, to choose between 31 different preparations. Of the 11 cows' milk preparations in powder and scoop form, there were seven different scoop sizes, ranging from 4.0 to 5.0 grams (table 3 ). In three cases, the same brand had three different scoop sizes. 
Table 2 Infant formulae on sale in one large supermarket chain in the UK, April 2002

\begin{tabular}{|c|c|c|c|c|}
\hline \multirow[b]{2}{*}{ Formulae } & \multicolumn{4}{|c|}{ Type of formulation } \\
\hline & $\begin{array}{l}\text { Ready to } \\
\text { feed* }\end{array}$ & $\begin{array}{l}\text { Simplifeed } \\
\text { system† }\end{array}$ & $\begin{array}{l}\text { Premeasured } \\
\text { sachets } \ddagger\end{array}$ & $\begin{array}{l}\text { Powder and } \\
\text { scoop§ }\end{array}$ \\
\hline \multicolumn{5}{|l|}{ Cows' milk, whey dominant } \\
\hline Aptamil First & 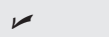 & - & - & 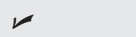 \\
\hline Cow \& Gate Premium & $\boldsymbol{r}$ & - & - & 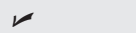 \\
\hline Farley's First & 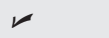 & $r$ & 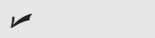 & $\checkmark$ \\
\hline Hipp Organic Infant & - & - & 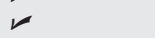 & r \\
\hline SMA Gold & $\boldsymbol{r}$ & - & 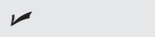 & レ \\
\hline \multicolumn{5}{|l|}{ Cows' milk, casein dominant } \\
\hline Aptamil Extra & レ & - & - & r \\
\hline Cow \& Gate Plus & 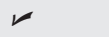 & - & - & 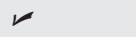 \\
\hline Farley's Second & 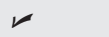 & $\boldsymbol{r}$ & 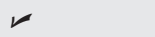 & $\checkmark$ \\
\hline Milumil & 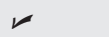 & - & - & r \\
\hline SMA White & $\swarrow$ & - & 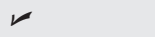 & 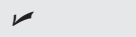 \\
\hline \multicolumn{5}{|l|}{ Cows' milk, $100 \%$ whey protein } \\
\hline Cow \& Gate Omneo Comfort 1 & - & - & - & 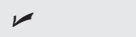 \\
\hline \multicolumn{5}{|l|}{ Soya based } \\
\hline Farley's Soya Formula & - & - & - & 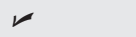 \\
\hline Infasoy (Cow \& Gate) & - & - & - & $v$ \\
\hline SMA Wysoy & $\boldsymbol{r}$ & - & - & レ \\
\hline \multicolumn{5}{|c|}{$\begin{array}{l}\text { *0.5-1 litre cartons and/or individual ready made feeds. } \\
\text { †Mixing equipment plus premeasured sachets of dry powder to make up around one pint ( } 0.56 \text { litre) of } \\
\text { reconstituted formula. } \\
\text { †Each sachet of dry powder sufficient to make up one feed-feed size varies between brands. } \\
\S \text { Large carton of dry powder and measuring scoop-scoop size varies within and between brands. }\end{array}$} \\
\hline
\end{tabular}

\section{DISCUSSION}

The most striking finding from this review is the paucity of information on a topic important to the health of large numbers of babies worldwide. In the UK alone, $31 \%$ of babies are fed breast milk substitutes from birth, and this number increases to around $79 \%$ by the time babies are 6 weeks old. ${ }^{12}$ Hundreds of thousands of babies each year in the UK, and many more worldwide, are completely dependent on the proper use of these products, yet we found no previous reviews on the reconstitution of feeds and only five relevant studies. All found that errors were made when reconstituting feeds, although none considered the wide range of products currently available.

The World Health Organisation Code on the marketing of breast milk substitutes, adopted in 1981, ${ }^{37}$ aims to "contribute to the provision of safe and adequate nutrition for infants, by the protection and promotion of breast feeding", and by "the proper use of breast milk substitutes, when these are necessary ..." (Article 1). However, since then, little attention has been paid to the second part of the Code's aim, either in practice or in research. In the UK in 2000, for example, of first time mothers attending antenatal classes and who intended to fully formula feed, only $9 \%$ were taught how to make up a bottle, ${ }^{12}$ and the National Audit Office report on the maternity services in 1997 did not consider artificial feeding at all in its examination of antenatal or postnatal care. ${ }^{38}$

Many of the new infant formulae are intended to reduce error although, paradoxically, they could have the opposite effect-for example, if a parent wishes to prepare a six ounce feed using premeasured four ounce individual sachets, one sachet might be used, plus an estimated half of another, potentially yielding more error than with traditional powder and scoop. The ways in which such sachets are actually used do not appear to have been investigated. Additionally, ready-to-feed preparations are expensive, and could result in a baby being given less feed than needed, or the feed being diluted with water or other liquids such as tea-a suggestion that the latter occurred was found in the study of low income mothers by McJunkin and colleagues. ${ }^{32}$ Without studies designed to examine such issues, it is impossible to advise either parents or health professionals on the relative merits of individual products.

The potential for harm resulting from over- or underconcentration of feeds is serious and includes both obesity and failure to thrive, as well as hypernatraemic dehydration. ${ }^{16-19}$ Furthermore, babies most likely to be artificially fed in westernised populations are those who come from lower socioeconomic groups ${ }^{12}$; these babies already suffer increased morbidity ${ }^{39}$ and their parents are those least likely to be able to afford the expensive ready-to-feed preparations. The price variation between products is considerable, with ready-to-feed preparations two or three times more expensive than powder and scoop (table 4). There is no unbiased source of information to help either parents or their advisers choose between brands, and between different ways of reconstituting

Table 4 Price ranges* of infant cows' milk formulations and between brands of powdered formula milk

\begin{tabular}{ll}
\hline Brand & Scoop sizes $(\mathrm{g})$ \\
\hline Cow \& Gate & $4.3,4.4,5.0$ \\
Farleys & $4.1,4.4,4.5$ \\
Hipp & 4.5 \\
Milupa & $4.3,4.6,5.0$ \\
SMA & 4.0 (assumed) \\
\hline
\end{tabular}

* Scoop sizes from products sold in one large supermarket chain in the UK, April 2002.

\begin{tabular}{ll}
\hline Type of formulationt & Price (pence per $100 \mathrm{ml}$ feed) \\
\hline Powder and scoop & $7.9-12.5$ \\
Premeasured sachets & $9.3-19.5$ \\
Simplifeed system & 9.4 \\
Ready-to-feed (largest carton) & $19.8-19.9$ \\
Ready-to-feed (individual feed) & $22.5-29.5$ \\
\hline
\end{tabular}

*Price ranges of products sold in one large supermarket chain in the UK, April 2002

†See footnotes to table 2 . 
feeds. Health professionals, like parents, have to rely on information produced by product manufacturers.

This review did not include issues related to the safety of breast milk substitutes in developing countries. Although many issues are similar, in developing countries there are additional risk factors to consider-for example, transport and availability of products, lack of clean water, the cost of artificial substitutes, and a lack of appropriate feeding equipment, manufactured to required standards. These are fundamentally important issues, especially in the light of the potential for HIV transmission through breast feeding, ${ }^{40}$ and the numbers of babies who need to be artificially fed as a result of their mother's illness or death. In the search for papers for this review, we identified only one paper related to feed reconstitution in a developing country context, indicating that the lack of evidence base is just as profound as in the western world. ${ }^{41}$ A full and proper assessment of the various risks associated with the use of breast milk substitutes is needed to inform this debate.

\section{Further research}

It is important to continue looking at ways to support women in initiating and maintaining breast feeding, enabling mothers to breast feed their babies for as long as they wish. ${ }^{8}$ In addition, however, it is important to minimise the risks associated with breast milk substitutes. Specifically, parents need to know which ways of giving their babies formula feeds are the simplest, most accurate, and cost effective. It is important to identify the outcomes as well as the sources of error in making up feeds-what contribution do they make to infant mortality and morbidity?

\section{Recommendations}

The range of ways in which manufacturers package and sell breast milk substitutes needs to be examined; they themselves recognise that risks are introduced in the reconstitution of their products. ${ }^{42}$ Some consistency in approach would be a step forward, perhaps moving towards uniform instructions and scoop sizes for the reconstitution of all products and brands. This would avoid confusion for parents when changing from one product to another, ${ }^{12}$ and help health professionals teach parents how to make up feeds more accurately.

A source of unbiased information is needed to inform parents and health professionals about the differences between the available formulae, including the different forms in which they are sold. In the UK there is an important role in this regard for both the Food Standards Agency and the Department of Health.

\section{Authors' affiliations}

M J Renfrew, K L Macleod, Mother and Infant Research Unit, University of Leeds, 22 Hyde Terrace, Leeds LS2 9LN, UK

P Ansell, Epidemiology and Genetics Unit, Margaret Smith Building, University of Leeds, 30 Hyde Terrace, Leeds LS2 9LN, UK

Contributors: The review was initiated by MR; MR and PA were involved in all its aspects. KLM contributed to early discussions, the identification and analysis of studies, and drafting of the paper. MR and PA act as guarantors.

\section{REFERENCES}

1 American Academy of Paediatrics. Working group on breastfeeding. J Pediatr 1997:100:1035-9.

2 Kramer MS, Chalmers B, Hodnett ED, et al. Promotion of Breastfeeding Intervention Trial (PROBIT): a randomized trial in the Republic of Belarus. JAMA 2001;285:413-20.

3 Howie PW, Forsyth JS, Ogston SA, et al. Protective effect of breast feeding against infection. BM 1990;300:11-16.

4 Wilson AC, Stewart Forsyth J, Greene SA, et al. Relation of infant diet to childhood heath: seven year follow up of cohort of children in Dundee infant feeding study. BMU 1998;316:21-5.

5 Gdalevich M, Mimouni D, David M, et al. Breast-feeding and the onse of atopic dermatitis in childhood: a systematic review and meta-analysis of prospective studies. J Am Acad Dermatol 2001;45:520-7.
6 Virtanen SM, Rasanen L, Aro A, et al. Feeding in infancy and the risk of type 1 diabetes mellitus in Finnish children. The "Childhood Diabetes in Finland" Study Group. Diabet Med 1992;9:815-19.

7 Mortensen EL, Michaelsen KF, Sanders SA, et al. The association between duration of breastfeeding and adult intelligence. JAMA 2002;287:2365-71.

8 World Health Organisation. Infant and young child nutrition: global strategy on infant and young child feeding. 55th World Health Assembly, Geneva, April 2002;A55/15.

9 Fairbank L, O'Meara S, Renfrew M, et al. A systematic review to evaluate the effectiveness of interventions to promote the initiation of breastfeeding. Health Technol Assess 2000;4:1-171.

10 Royal College of Midwives. Successful breastfeeding, 3rd edn Edinburgh, London: Churchill Livingstone, Harcourt Health Sciences, 2000.

11 UNICEF. Baby friendly hospitals show strong increase in breastfeeding rates. Baby Friendly News, 6. UK Baby Friendly Initiative, 2000.

12 Hamlyn B, Brooker S, Oleinikova K, et al. Infant feeding 2000. London: TSO, 2002

13 Renfrew MJ, Woolridge MW, Ross McGill H. Enabling women to breastfeed. A review of practices which promote or inhibit breastfeeding - with evidence-based guidance for practice. London: The Stationery Office, 2000

14 World Health Organisation. The Innocenti Declaration: progress and achievements. Weekly Epidemiological Record 1998;73:25-30,9194,139-44.

15 Division of Child Health and Development, World Health Organisation. Evidence for the ten steps to successful breastfeeding. WHO/CHD/98.9. Geneva: World Health Organisation, 1998

16 Department of Health and Social Security. Present day practice in infant feeding. Report on health and social subjects 9. London: HMSO 1974.

17 Chambers TL, Steel AE. Concentrated milk feeds and their relation to hypernatraemic dehydration in infants. Arch Dis Child 1975;50:610-15.

18 Sunderland R, Emery JL. Apparent disappearance of hypernatraemic dehydration from infant deaths in Sheffield. BM 1979:2:575-6.

19 Davies DP, Ansari BM, Mandal BK. The declining incidence of infantile hypernatraemic dehydration in Great Britain. Am J Dis Child 1979;133: 148-50

20 Taitz LS, Byers HD. High calorie/osmolar feeding and hypertonic dehydration. Arch Dis Child 1972;47:257-60

21 Oates RK. Infant-feeding practices. BM 1973;2:762-4.

22 Wilkinson PW, Noble TC, Gray G, et al. Inaccuracies in measurement of dried milk powders. BM 1973;2:15-17

23 Smith BAM. Feeding overstrength cows' milk to babies. BM 1974;4:741-2

24 De Swiet $\mathbf{M}$, Fayers $\mathrm{P}$, Cooper L. Effect of feeding habit on weight in infancy. Lancet 1977;1:894-7.

25 Jones RAK, Belsey EM. Common mistakes in infant feeding: survey from a London borough. BM 1978;2:112-15

26 Department of Health and Social Security. Present day practice in infant feeding: 1980. Report on Health and Social Subjects 20. London: HMSO, 1980.

27 Ministry of Agriculture Fisheries and Food. The infant formula and follow-on regulations 1995. Statutory Instrument 77. London: HMSO 1995.

28 Laing A, Wong CM. Hypernatraemia in the first few days: is the incidence rising? Arch Dis Child Fetal Neonatal Ed 2002;87:F158-62.

29 Oddie S, Richmond S, Coulthard M. Hypernatraemic dehydration and breast feeding: a population study. Arch Dis Child 2001;85:318-20.

30 Eke F, Nte A. A prospective clinical study of patients with hypernatraemic dehydration. Afr J Med Med Sci 1996;25:209-12.

31 Jacob F. Infant care: getting it right. Community Outlook 11 December 1985:20-1

32 McJunkin JE, BithoneyWG, McCormick MC. Errors in formula concentration in an outpatient population. J Pediatr 1987:111:848-50.

33 Lilburne AM, Oates RK, Thompson S, et al. Infant feeding in Sydney; a survey of mothers who bottle feed. Aust Paediatr J 1988;24:49-54.

34 Jeffs SG. Hazards of scoop measurements in infant feeding. J R Coll Gen Pract 1989:39:113.

35 Lucas A, Lockton S, Davies PSW. Milk for babies and children [letter] BM 1991;302:350-1.

36 Lucas A, Lockton S, Davies PSW. Randomised trial of a ready-to-feed compared with powdered formula. Arch Dis Child 1992;67:935-9.

37 World Health Organisation. International Code of Marketing of breast-milk substitutes. WHO: Geneva, 1981.

38 Department of Health. First class delivery: improving maternity services in England and Wales. London: The Audit Commission UK, 1997.

39 Pattenden S, Dolk H, Vrijheid M. Inequalities in low birth weight: parental social class, area deprivation, and "lone mother" status. Epidemiol Community Health 1999;53:355-8.

40 WHO, UNICEF, and UNAIDS. Statement on current status of WHO/UNAIDS/UNICEF policy guidelines on HIV and infant feeding. Geneva: WHO, 1999

41 Suriono D, Ismadi SD, Suwardii, et al. Bacterial contamination and dilution of milk in infant feeding bottles. J Trop Pediatr 1980;26:58-61

42 IDACE (Association des industries des aliments dietetiques de I'Union Europeene); Association of the Food Industries for particular nutritiona uses of the European Union. Statement on the hygiene of powdered formula intended for infant. 02/140. July 2002. 